\title{
DIE STRATEGIESE KERNVLOOT EN 'N KERNLUGVERMOË
}

Lt T van Rensburg*

The development of a nuclear navy and nuclear air power is discussed with regard to the deterrent value of nuclear weapons, especially demonstrated by the ability to survive in the event of opposing nuclear aggression.

\section{Inleiding}

Die supermoondhede se strategiese kernvermoëns is saamgestel uit drie belangrike bene, te wete landelik-ontplooide interkontinentale ballistiese kernmissiele, ' $n$ kernvloot en 'n kernlugvermoë. Hierdie samestelling, ook genoem die strategiese kerntriade ('strategic triad'), verteenwoordig die verspreiding van die kernmoondhede se 'kernslaankrag' oor 'n wye front, om onder andere verskeie moontlikhede te bied vir die aanwending van kerwapens in geval van kernkonflik. In kernstrategie is die afskrikkingswaarde van kernwapens van deurslaggewende belang, veral gedemonstreer in die vermoë tot kernvergelding in geval van opponerende kernaggressie. Die strategiese kerntriade is dus ' $n$ belangrike samestelling om ' $n$ kernmoondheid te verseker van omvattende oorlewingspotensiaal. Die waarde van oorlewingspotensiaal in 'n kernafskrikkingstrategie is alleen geldend indien dit in die wydste sin van die woord polities-strategies sowel as militêr-tegnologies in stand gehou en gerugsteun word. Die ontwikkeling van die kernvloot en 'n kernlugvermoë word in die lig van die voorafgaande verder toegelig.

\section{Die ontwikkeling van die vloot tot moderne strategiese magskomponent}

Met bykans 'n driekwart van die aarde se opper- vlakte onder sy vleuls, bied die see 'n feitlik aaneengeslote en deurlopende medium vir beweging, sonder die ontwrigtende terreinomstandighede van die land waarlangs en die bodem waaroor dit vloei. Die invloed van die see op die geskiedenis van die mensdom vind sy beslag in 'n rykdom van gebeurtenisse, waarvan die oorlewingsark van Noag tydens die sondvloed, die benutting van die Nylrivier vir primitiewe vervoerdoeleindes deur die Egiptenare 6000 v.C., en die ontdekkingsreise van die seevarende Dias en Columbus, maar enkele voorbeelde is. Strategie ter see vind egter sy grondlegging in die wyd verkondigde boodskap van Mahan, die sogenaamde 'Evangelist of Sea Power', dat die mag van die oseane ten bate lê van die lande wat die ontwikkeling en beheer daarvan die beste kan benut. $^{1}$

Verskeie ontwikkelingstadia kan aangestip word as momente wat die vloot uitgelig het tot moderne strategiese magskomponent. Enkele vroeë momente wat aangedui kan word, is die toetrede van die eerste duikboot (1774), die eerste stoomskip (1814) en die eerste pantserskip (1865) tot die vloot. So was die eerste sending van ' $n$ duikboot die plaas van 'n torpedo onder aan die buik van 'n vyandelike skip, waar dit dan met behulp van 'n tydmeganisme sou ontplof as die duikboot weer buite gevaarafstand is. Die enkele belangrikste gebeurtenisse in die moderne geskiedenis van die vloot is die ter water lating van die eerste kernaangedrewe

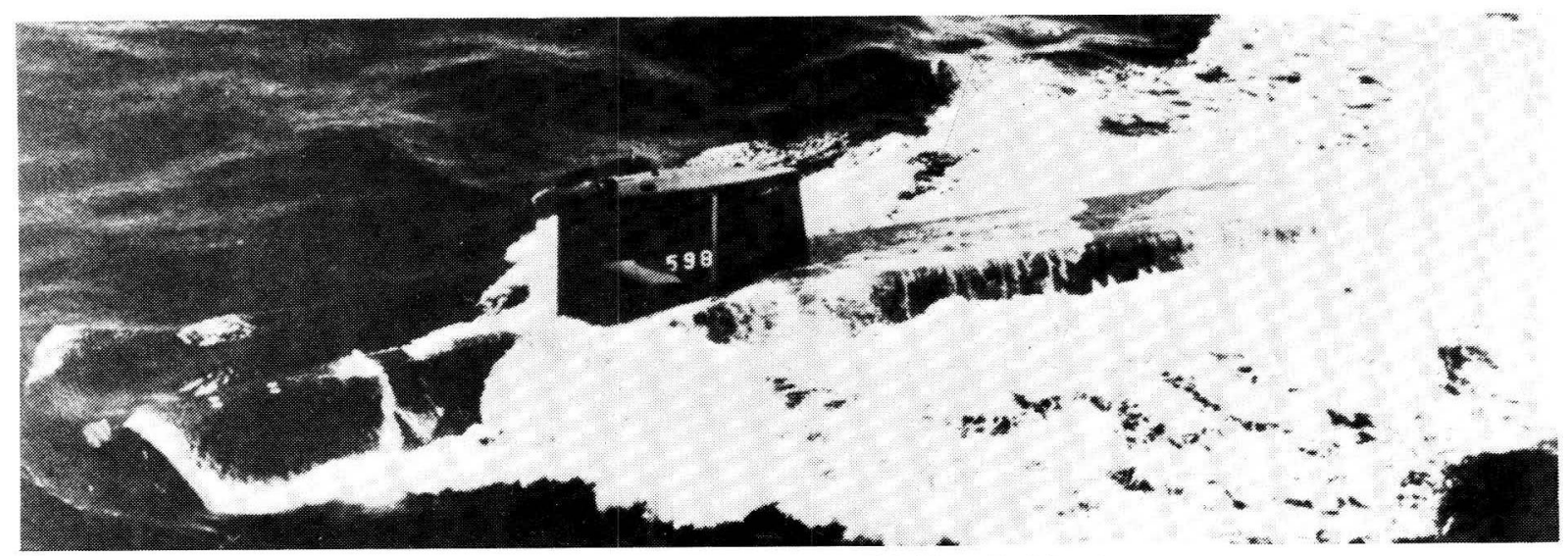

Die George Washington - 'n VSA-Vloot Duikboot

(Foto: Jane's Fighting Ships) 
duikboot, die Nautilus, op 17 Januarie 1955, en die daaropvolgende ter water lating van die eerste kernduikboot wat ballistiese missiele sou dra, die George Washington, op 9 Junie 1959.2

Die strewe na die beheer oor die oseane is ' $n$ onderwerp wat wye vertolking behoef en nie gereduseer kan word tot enkele statistiese gegewens van sekere vlootkomponente nie, soos Brodie tereg opmerk: 'Sea power has never meant merely warships'. ${ }^{3}$ Sokol se vertolking kan in hierdie verband soos volg weergegee word: 'Sea power is a positive capability which confers on its possessor great economic and peaceful benefits; as an additional advantage it also offers him a particularly favourable chance to wage and win wars in the pursuit of his national objectives'. ${ }^{4}$

Teen die agtergrond va die voorafgaande vertolking het die vermoë van die vloot besondere betekenis in die strewes wat politieke en militêre dominerende oogmerke voorafgaan. Die vloot maak vandag deel uit van een van die drie bene van die strategiese kerntriade wat die ewewigtige verspreiding van kernvergeldingsvermoëns ten doel het. Die vloot wat sy tradisionele taakvervulling vind in beheer oor die oseane en beskerming van nasionale belang teen vyandelike aggressie, het met die ontwikkeling van die kernvloot ook die taakvervullende afskrikkingstrategie verkry waar dit van ver buite vyandelike waters tot diep binne die opponerende hartland kan dring - 'n taakvervulling wat soos volg deur Sokol omskryf word: 'By thus increasing our 'strategic' capability, sea power assumes an important role in deterring wars as well as winning them'. 5

\section{Die kernduikboot}

Die kernduikboot, met sy afleweringsvermoë vir kernmissiele, is die sentrale komponent van die strategiese kernvloot. Die kernduikboot het met sy onderwater maneuvreergebied besliste voordelige oorlewingsaspekte in sy guns en vorm in wese 'n aangepaste voortsetting van dit wat met landelik-ontplooide strategiese kernvermoëns bereik wil word. Stanford verduidelik hierdie aspek soos volg: 'Nuclear-missile submarines are, quite simply, underwater missile bases'. ${ }^{6}$

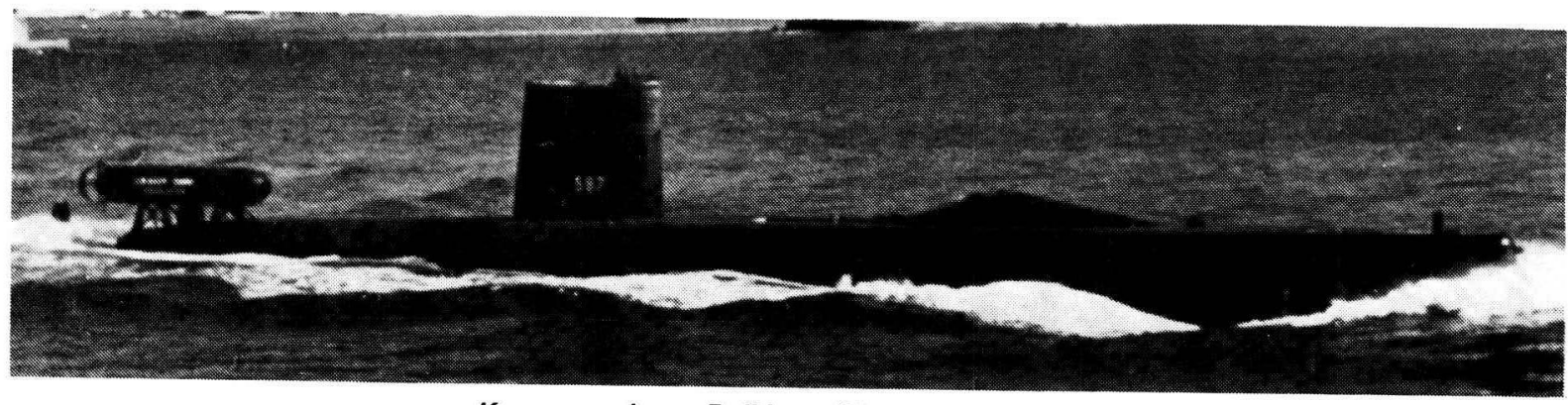

Kernaangedrewe Duikboot (Halibut VSA-Vloot) (Foto: Jane's Fighting Ships)

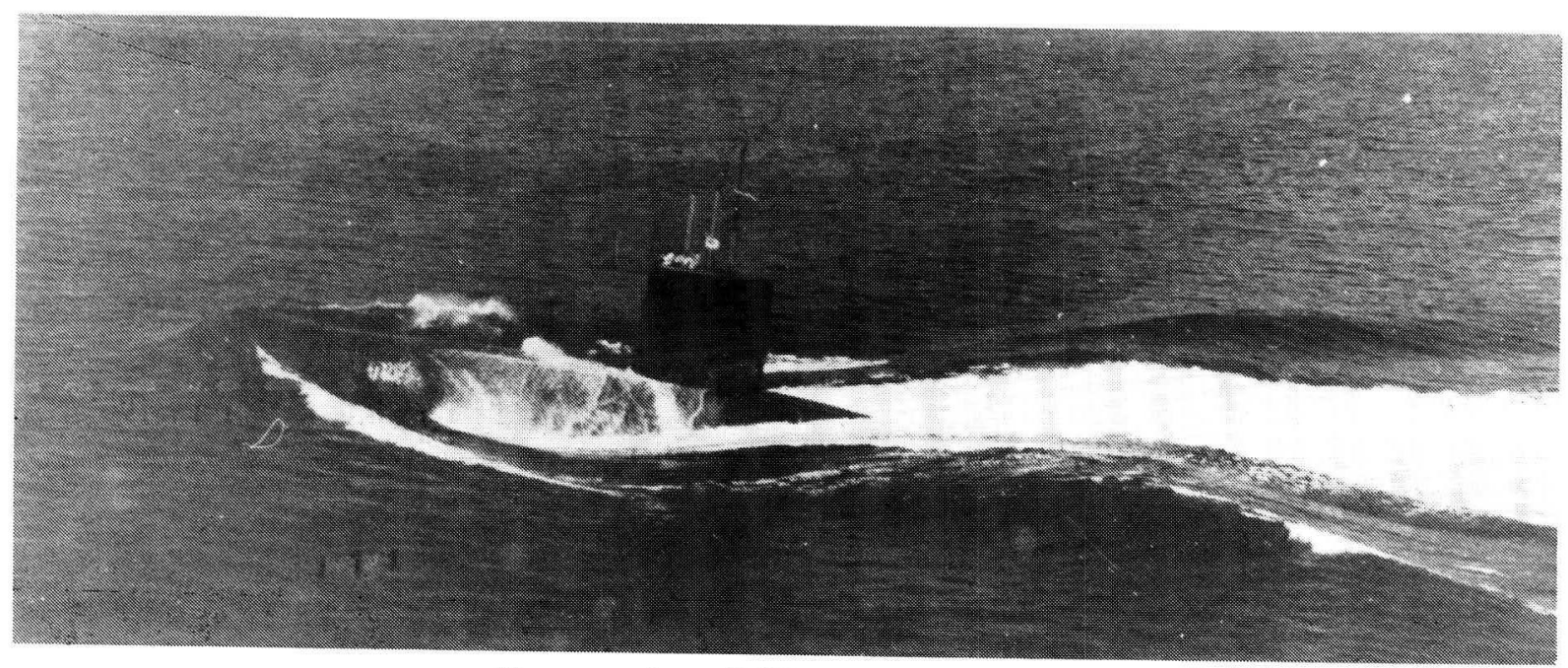

Kernaangedrewe Duikboot: HMS Dreadnought 
Verskillende tipes duikbote word van mekaar onderskei op grond van die aanwending daarvan, waarvan die belangrikste onderskeiding geleë is in die afleweringsvermoë vir kernwapens en die vermoë vir 'gevegte' ter see - onderskeidelik 'ballistic missile submarines' en 'attack submarines'. Duikbote kan hierbenewens in 'n verskeidenheid rolle aangewend word, soos onder andere die tradisionele beskermingsrol, van belangrike seeroetes, begeleiding van belangrike militêre- en handelsendings, opsporing en rinonitor aangeleenthede. ${ }^{7}$

Ten einde die vermoë van die strategiese kernduikboot na waarde te skat moet daar breedweg op drie aspekte gelet word, naamlik die duikboot self, kernmissiele en noodsaaklike ondersteuningsfasiliteite. Die duikboot het met die ter water lating van die Nautilus 'n nuwe era in moderne tegnologie betree. Kernaandrywing het dit moontlik gemaak dat duikbote, tegnies gesproke, feitlik vir 'n onbepaalde tyd onder die water kan bly. Die tydperk vir onderwaterverblyf word slegs aan bande gelê deur voedselvoorrade en die uithouvermoë van die bemanning. Drie klasse duikbote kan in die VSA se kernvloot onderskei word: die George Washington-reeks (ongeveer 115 meter in lengte met ' $n$ verplasingstonnemaat van 6700 ton) wat met die A3 Polaris-missiel toegerus is; die Ethan Allenreeks (ongeveer 123 meter in lengte met ' $n$ verplasingstonnemaat van 7900 ton) wat ook die Polaris-missiel dra; en die Lafayette-reeks (ongeveer 128 meter in lengte met ' $n$ verplasingstonnemaat van 8250 ton) wat met die Poseidon C3-missiel toegerus is. ${ }^{8}$

Die nuutste uitbreiding van bogenoemde klasseindeling is die ontwikkeling van die Ohio-reeks wat met die nuwe Trident C4-missiel toegerus gaan word. Die nuwe Trident duikboot, met 'n verplasingstonnemaat van 18000 ton, is vyf keer groter as die eerste kernduikboot en kan met vier-en-twintig kernmissiele toegerus word in stede van die sestien missiele van die Polaris- en Poseidon duikbote. Die Amerikaanse kongres handhaaf ' $n$ verdeelde standpunt oor die ontwikkeling van die Trident duikboot, maar dit moet vir algemene evaluasie doeleindes in gedagte gehou word dat al die bestaande Amerikaanse duikbote gedurende die laat tagtigerjare twintig jaar of ouer sal wees, en gevolglik mettertyd uit pas sal raak met die vereistes vir oorlewingskapasiteit. $^{9}$

Die missiele van die Amerikaanse kernvloot sien soos volg daar uit: die Polaris A3 met $3 \times 200$ kiloton (KT) kernplofkoppe en 'n reikafstand van 4600 kilometer; die Poseidon C3 met $10 \times 50$ KT kernplofkoppe en dieselfde reikafstand as die Polaris; en die Trident C4 met $8 \times 100 \mathrm{KT}$ kernplofkoppe en 'n reikafstand van 7400 kilometer. Die Trident $C 4$ is ' $n$ drie-fase missiel, in teenstelling met die twee-fase Polaris en Poseidon, en kan die reikafstand van laasgenoemde twee missiele feitlik verdubbel. Die Trident-missiel wat vir die Ohio duikbootreeks ontwerp is, is ook reeds op drie van die Lafayette-klas duikbote ontplooi. ' $n$ Trident II-missiel, wat 'n uitbouing van die eerste Trident-reeks is, word ontwerp as die finale missiel waarmee alle Trident duikbote mettertyd toegerus kan word. ${ }^{10}$

In die laaste plek berus die vermoë van 'n kernvloot op noodsaaklike ondersteuningsfasiliteite met betrekking tot bevel en beheer-aspekte, onderhoud en aanvulling ter see, die deurlopende bepaling van posisie ten einde akkurate missielaflewering te bewerkstellig en landwaartse ondersteuning, soos byvoorbeeld opleiding van personeel en die modernisering van uitrusting soos wat dit van tyd tot tyd vereis mag word. ${ }^{11}$

\section{Die betekenis vn 'n moderne strategiese kernvloot}

Die strategiese kernvloot, gekonsentreer in kernduikbote met 'n kernmissielafleweringsvermoë, is ' $n$ belangrike been van die kerntriade en dien as aanvullende en ondersteunende vergeldingsvermoë ten einde die doelwit van oorlewingspotensiaal te verwesenlik. Die kernvloot is ' $n$ vergeldingsvermoë in die eerste plek (nie geskik vir 'n openingsaanval nie vanweë sy onvermoë om 'harde' militêre teikens te vernietig) en lewer gevolglik 'n stabiliteitsbydrae ten gunste van 'n afskrikkingstrategie. Hierbenewens sou die vernietiging van ' $n$ kernduikboot in die deurlopende risiko van tussenstaatlike kernterreur die hartland van die supermoondhede ongeskonde laat en die glyskaal van kernterreur vertraag. ${ }^{12}$

Die Poseidon kernduikboot wat sestien missiele dra, elke met tien kernplofkoppe (MIRV) waarvan een plofkop rofweg drie 'Hirosjimas' verteenwoordig, illustreer argumentsonthalwe die potensiaal wat in 'n kernduikboot opgesluit lê. Hierdie potensiaal word verder ondersteun deur aspekte soos mobiliteit, relatiewe onkwesbaarheid, sowel as die maneuvreerbare aanwending van duikbote. Indien die reikafstand van duikbootgelanseerde kernmissiele verhoog, vergroot die 
ondersese skuilingsarea vanwaar nog effektief teen die kernopponent opgetree kan word. In terme van bogenoemde eienskappe beskik die kernduikboot oor voordele wat nie buite rekening gelaat kan word met die oog op moderne strategiese kernvermoëns nie. ${ }^{13}$

Sekere beperkende aspekte ten opsigte van die kernvloot verdien ook vermelding ter wille van 'n gebalanseerde oorsig. Die volgende kan in hierdie verband aangedui word: die kernduikboot konsentreer 'n relatief groot verteenwoordiging van kernslaankrag; verskeie opsporingsmaatreëls ('anti-submarine warfare') verhoog die kwesbaarheid van die duikboot sodat wanneer dit eers opgespoor is dit ' $n$ relatief maklik uitwisbare teiken is; en vanweë sy mobiliteit is navigasie en posisionele presiesheid, sowel as bevel en beheer-aspekte, probleemareas wat van deurslaggewende belang is in die duikboot se vermoë om akkurate en tydig gelanseerde kernmissiele af te lewer. ${ }^{14}$

\section{'n Strategiese kernlugvermoë}

\section{Strategiese lugbombardement}

Lugbombardement het sy oorsprong by bemande lugballonne waaruit bomme na spesifieke teikens laat val is. Hierdie konsep van lugbombardement wat in 1849 vir die eerste keer militêr toegepas is, kon egter eers met die ontwikkeling van die vliegtuig - sedert die demonstrasie van die Wright broers in 1903 - tot betekenisvolle konsekwensies gevoer word. Selfs laasgenoemde ontwikkeling was traag om operasioneel gedurende die Eerste Wêreldoorlog beslag te kry, sodat die bomwerper nie sy deurslaggewende rol in strategiese bombardement kon illustreer nie. Clark skryf die volgende na aanleiding van bogenoemde traagheid met spesifieke verwysing na die British Royal Flying Corps (gestig in 1912) se Army Wing; 'To the officers of the Army Wing in its early days, the earoplane was primarily an airborne horse, a

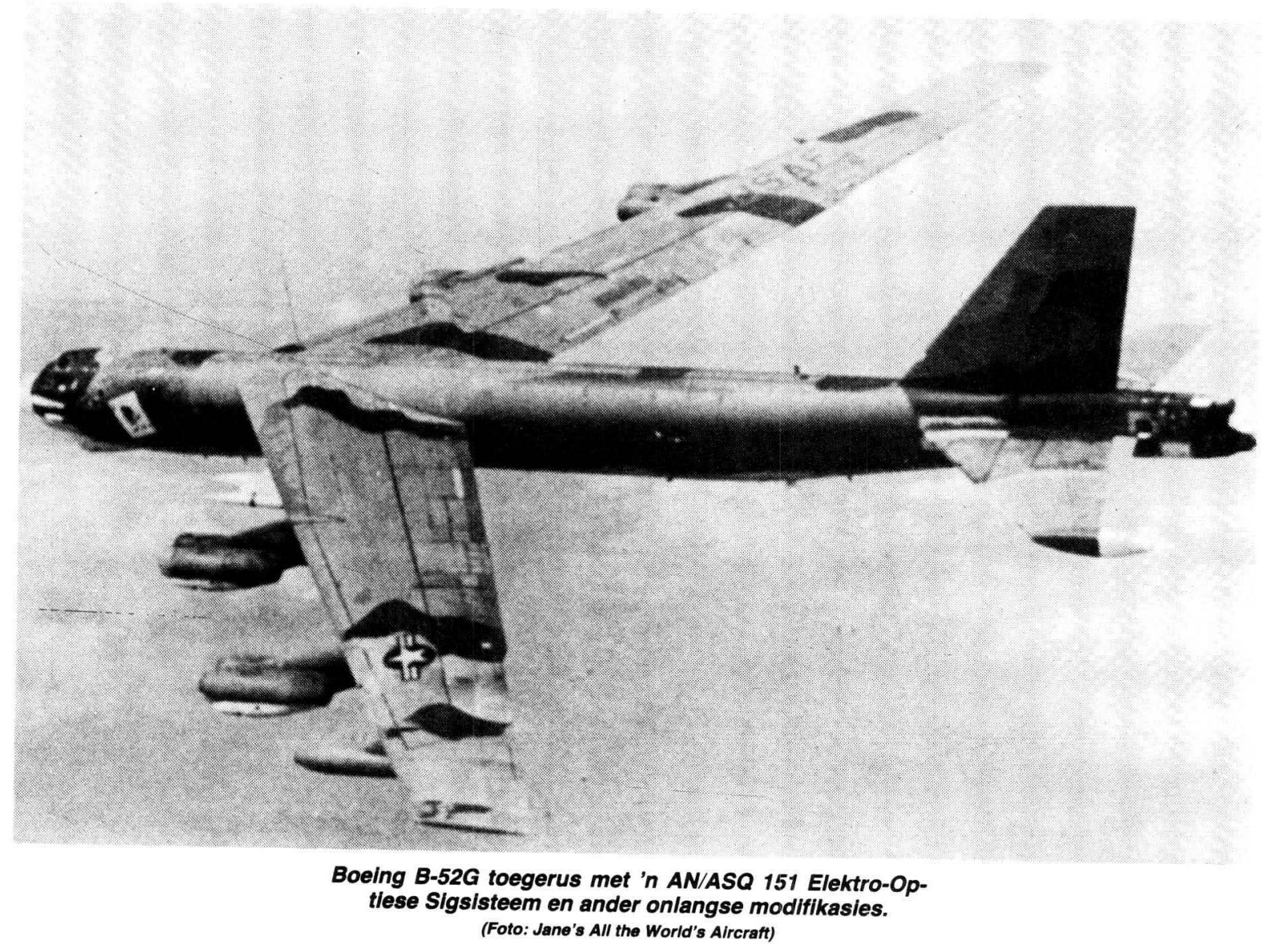


mount which could carry its riderpilot across enemy lines and bring him back with the latest information on what the enemy was doing', ${ }^{15}$

Die Tweede Wêreldoorlog was egter gekenmerk deur volgehoue lugbombardement en is uiteindelik afgesluit deur die strategiese bombardement van Hirosjima en Nagasaki - vir alle praktiese doeleindes die enigste ondervinding in strategiese lugbombardement. 'n Amerikaanse B-29 bomwerper, onder bevel van kolonel Tibbets, het op 6 Augustus 1945 die eerste sending van strategiese bomwerpers voltooi met die neerlating van die atoombom oor Hirosjima. Die bomwerper was in die begin van die kerneeu die enigste tegnologiese uitvoerbare oplossing vir die aflewering van uitsonderlike swaar bomme en moes feitlik slegs oor die noodsaaklike reikafstand en dravermoë beskik het wat vir sodanige operasies vereis was. Die resultaat was egter drasties van aard, soos Brodie tereg opmerk: 'The effectiveness of strategic bombing as a way of war could no longer be questioned. It at once became, incontrovertibly, the dominant form of war'. ${ }^{16}$

Die aflewering van strategiese kernwapentuig het vir hedendaagse doeleindes, benewens die strategiese bomwerper, ook na ander vorme van aflewering verskuif soos die interkontinentale ballistiese missiel en die kernduikboot. Die bomwerper het egter nie as gevolg van moderne verwikkelinge in die niet verdwyn nie, maar het eerder tegnologies vooruit gegaan sodat dit vandag steeds 'n belangrike komponent van die strategiese kerntriade is. ${ }^{17}$

\section{Die rol van die strategiese bomwerper in die kerneeu}

Die bomwerper beklee 'n unieke rol in totale strategiese kernvergeldingsvermoëns deurdat dit oor sekere voordele beskik wat nie by die kernduikboot of interkontinentale balistiese missiele aanwesig is nie. Dit is alleen die bomwerper wat tydens vroeë waarskuwing reeds op sy sending kan vertrek ('launch on warning'), terwyl die juistheid van die waarskuwing intussen vasgestel kan word of terwyl daar deur onderhandelings gepoog word om die krisissituasie te ontlont. Uit die voorafgaande spruit dit dat die bomwerper ook die enigste been van die strategiese kerntriade is wat na lansering herroep kan word. Anders as kernmissiele is die bomwerper herbruikbaar en kan dit herbewapen word. Die totale kapasiteit van Amerikaanse strategiese kernlugvermoëns (dravermoë van bomwerpers) is hierbenewens meer as die gesamentlike kernvermoëns wat op land of ter see ontplooi is. ${ }^{18}$

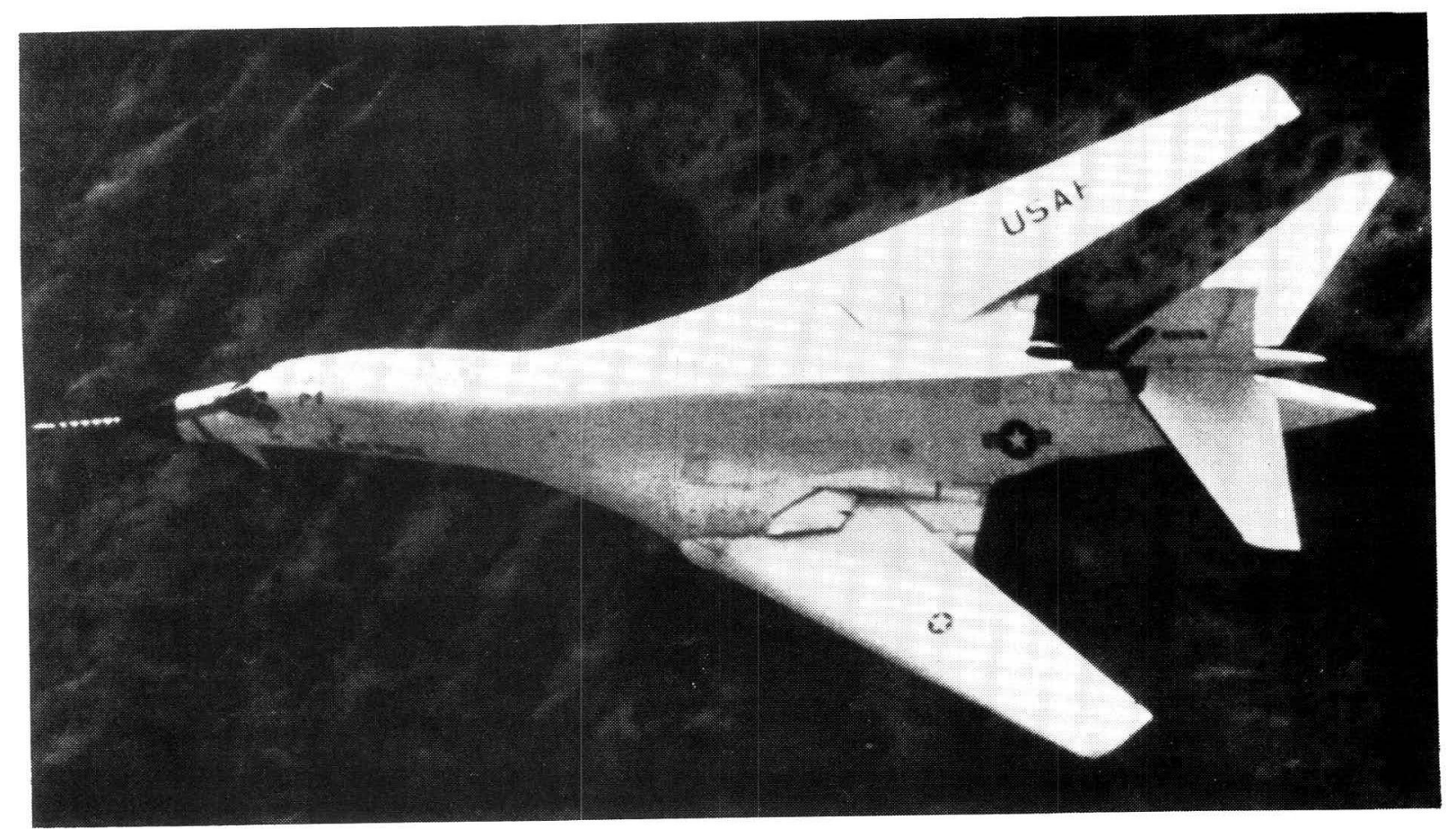

B-1 Strategiese Bomwerper (Foto: Jane's All the World's Aircraft) 
Verskeie ander aspekte tel in die guns van die strategiese bomwerper. Bomwerpers kan na gelang van die behoefte na verskillende lugmagbasisse verskuif word en behels daarom die verspreiding van strategiese lugvermoëns oor 'n wye front. Uit die voorafgaande is dit ook duidelik dat totale kernvermoëns as gevolg van dié verspreiding 'n teikenveelheid aan die kernopponent se uitwissingsproblematiek toevoeg. Met langafstandaflewering kan die strategiese bomwerper ' $n$ hoë mate van akkuraatheid behaal en kan dit ter eniger tyd ook vir alternatiewe sendings ingespan word. Die buigsaamheid van die bomwerper is verder daarin geleë dat dit in 'n strategiese sowel as konvensionele rol aangewend kan word. 'n Geloofwaardige kernlugvermoë noodsaak die kernopponent om hom veral op verdedigingsaspekte toe te spits en is ' $\mathrm{n}$ relatief goeie waarborg vir teenprestasie indien tegnologiese deurbrake die rol van die kernduikboot of die ICBM lam sou lê. ${ }^{19}$

Die bomwerper het oor die algemeen ' $n$ besonder gunstige strategiese aanwendingsvermoë en is trouens ' $n$ goeie fisiese demonstrasie van vergeldingsvermoë vir doeleindes van afskrikkingsoogmerke. Senator Barry Goldwater het hierdie sigbare vermoë soos volg omskryf: 'The manned penetrating bomber can ... provide a highly visible deterrent force, one that can be used as a recognizable expression of national determination and resolve in either preplanned or ad hoc contingency situations'. ${ }^{20}$

Die oorlewingskapasiteit van die strategiese bomwerper berus hoofsaaklik op twee deurslaggewende aspekte, naamlik kwesbaarheid voor lansering, waar vroeë waarskuwing en reaksievermoë van deurslaggewende belang is, en sy deurdringingsvermoë tot vyandelike teikens. Reaksievermoë berus breedweg gestel op tydige waarskuwing, die waaksaamheid van die bemanning, die algemene vaartbelyning van reaksiefasiliteite en die eienskappe van die bomwerper om sodanig te reageer. Deurdringingsvermoë van die vyandelike verdedigingsnetwerk is in die laaste plek een van die grootste probleme waarmee die strategiese bomwerper te kampe het, alhoewel dit nie in alle omstandighede die vyandelike lugruim hoef binne te dring nie, soos byvoorbeeld deur die lansering van kruisermissiele ver vanaf die vyandelike hartland. ${ }^{21}$

\section{Modernisering van die strategiese kernlugvermoë}

Die reeks van B-52 bomwerpers is etlike jare reeds die hoeksteen van die Amerikaanse kernlugvermoë en het verskeie moderniseringsprosesse deurloop, alhoewel die laaste B-52 in 1962 vervaardig is. Verskillende standpunte is waarneembaar ten opsigte van die noodsaaklikheid van 'n moderniseringsprogram vir strategiese bomwerpers al dan nie. Daar behoort egter rekening gehou te word met noodsaaklike moderniseringsvereistes vir die strategiese bomwerper aangesien die B-52 reeds ' $n$ omvangryke leeftyd agter die rug het en teen 1990 nouliks doeltreffend as vergeldingsvermoë sal kan funksioneer. Gesien in die lig van die strategiese aanwendbaarheidsvermoë van die bomwerper en die noodsaaklikheid van deurlopende oorlewingskapasiteit ten gunste van algemene oorlewingspotensiaal, kan moderne kernlugvermoëns tot die jaar 2000 beslis nie afhanklik wees van bomwerper-tegnologie wat uit die vyftiger- en sestigerjare dateer nie. ${ }^{22}$

Die twee belangrikste moderniseringsprogramme wat in bogenoemde verband ter sprake is, is die wyeromp Boeing 747 wat geoormerk is om met kruisermissiele (ALCM) toegerus te word, en die B-1 bemande bomwerper vir die deurdringing van vyandelike lugverdedigingsnetwerke. Die wyerompbomwerper kan egter baie kwesbaar wees en gevolglik minder gunstige oorweging geniet. Volgens The Military Balance 1980-1981 gaan al 151 Amerikaanse B$52 \mathrm{G}$ bomwerpers mettertyd aangepas word om met die kruisermissiel toegerus te kan word. ${ }^{23}$

Die B-1 bomwerper, waarvan die vervaardiging in 1977 deur president Carter gestop is, word bestempel as een van die vernaamste tegnologiese verbeterings op die B-52 reeks. Ellis skryf soos volg hieroor: 'The B-1 represents a 15-year step forward in bomber technology. It's quick response capability permits it to get into the air fast, thus making it extremely difficult to successfully attack on the ground. It can fly low, under technologically advanced enemy defences, and reach enemy targets deep in an enemy's heartland with large payloads' ${ }^{24}$ Samevattend beskik die B-1 bomwerper dus oor die vermoë om: twee keer vinniger en oor ' $n$ korter afstand as die B-52 op te styg; groter weerstand te bied by die blootstelling aan kernontploffings; sub-soniese spoed op baie lae hoogtes te bereik, waardeur vyandelike radaropsporing bemoeilik word; en om oor 'n groter dravermoë as die B-52 te beskik. In sy geheel beskou is die B-1 bomwerper ontwerp om aan die sleutelvereistes vir oorlewingskapasiteit in kernstrategie te voldoen. ${ }^{25}$ 


\section{Slot}

Die strategiese belangrikheid van die kernvloot en ' $n$ kernlugvermoë word veral beklemtoon in die lig van die kwesbaarheid van die VSA se ondergrondse silogebergte interkontinentale ballistiese missiele. (Die ontwikkeling van die MX-missiel en beskerming daarvan by wyse van mobiliteit en meervoudige bergingsteikens is ' $n$ teenvoeter vir bogenoemde kwesbaarheidskrisis). 'n Kerndebat wat die 'kernpolitiek' in beroering sal bring en waar dit sal handel oor 'n strategiese kerntriade versus 'n tweebenige strategiese kernvermoë (laasgenoemde met die landelik-ontplooide ICBM weggelaat), word selfs in die vooruitsig gestel. ${ }^{26}$ Wat egter van belang is, is dat die kerneeu vereis dat die oorlewingspotensiaal van die kernmoondhede oor ' $n$ wye front gehandhaaf moet word. Alleen dan kan gereken word op 'n strategie van kernafskrikking ten gunste van die delikate terreurbalans van die kerneeu. Hierin speel die kernvloot en 'n kernlugvermoë 'n belangrike rol.

*Lt T. van Rensburg, MA het sy graad aan die begin van 1981 met lof aan die Universiteit van die OVS behaal.

\section{Voetnotas}

1. Vgl. Sokol, A.E., Seapower in the Nuclear Age, Public Affairs Press, Washington, 1961, pp. 62-70; Sprout, M.T., Mahan: Evangelist of Sea Power, in Earle, E.M. (red.), Makers of Modern Strategy, Princeton University Press, Princeton, 1971, pp. 415-445.

2. Vgl. Brodie, B., Sea Power in the Machine Age, Greenwood Press, New York, 1969, pp. 18, 147, 263; Hewlett, R.G., Duncan, F., Nuclear Navy, 1946-1962, University of Chicago Press, Chicago, 1974, pp. 399-401.

3. Brodie, B., A Guide to Naval Strategy, Frederick A. Praeger, New York, Vyfde uitgawe, 1965, p. 2.

4. Sokol, A.E., op. cit., p. 56

5. Vgl. Ibid., p. 83. Vgl. ook Burns, T.S., The Secret War for the Ocean depths. Soviet-American Rivalry for Mastery of the Seas, Rawson Associates Publishers, New York, 1978, pp. 4-5: 'The covert struggle for control of the world hydrospace has become a paramount interest to the two superpowers; it is over, on, and particularly under the oceans of the world that the struggle for political and military domination will eventually be decided'

6. Stanford, P., Nuclear Missile Submarines and Nuclear Strategy, in Johnson, D.T., Schneider, B.R. (reds.), Current Issues in U.S. Defence Policy, Preager Publishers, New York, 1976, p. 154.

7. Vgl. Burns, T.S., op. cit., p. 75; Eleson, P., The Undersea Challenge, in National Defence, Vol. LXI, No. 340, Januarie/Februarie 1977, pp. 275-276.

8. Vgl. Siuru, W.D., SLBM - the Navy's Contribution to Triad, in Air University Review, Vol. XXVIII, No. 6, September/Oktober 1977, pp. 23-26; Stanford, p., op. cit., p. 155-158.

9. Vgl. Siuru, W.D., op. cit., pp. 26-29; Stanford, P., op. cit., p. 158; The Military Balance 1980-1981, uitgegee deur The International Institute for
Strategic Studies, London, Autumn 1980, p. 3; Rathjens, G.W., Ruina, J.P., Trident, in Tsipis, K., Cahn, A.H., Feld, B.T. (reds.), The Future of the Sea-based Deterrent, The MIT Press, Massachusetts, 1973, pp. 53-76; Burns, T.S., op. cit., p. 248: 'The new Trident submarine is projected as an amazing feat of naval engineering ... It will be quieter, faster, and more maneuverable and have improved sonar capabilities. It will also be simpler to maintain and overhaul, able to spend far more time at sea.'

10. Vgl. Siuru, W.D., op. cit., pp. 23-25, 28; The Military Balance 1980-1981 ..., pp. 5,88 .

11. Vgl. Siuru, W.D., op. cit., pp. 25-26; Stanford, P., op. cit., pp. 155, 160-165.

12. Vgl. Speed, R.D., Strategic Deterrence in the 1980's, Hoover Institution Press, Stanford, 1979, p. 86; Rosenthal, M., Some Aspects of Sea-based Deterrent Strategies, in Quester, G.H. (red.), Sea Power in the 1970's, Dunellen, New York, 1975, pp. 186-196.

13. Vgl. Rosenthal, M., op. cit., pp. 187-188; Stanford, P., op. cit., pp. 154-156; Siuru, W.D., op. cit., pp. 18-19.

14. Vgl. Speed, R.D., op. cit., pp. 56-63; Siuru, W.D., op. cit., pp. 19-22; Brown, N., Deterrence from the Sea, in Survival, Vol. XII, No. 6, Junie 1970, pp. 194-198; Scoville, H., Missile Submarines and National Security, in Scientific American, Vol. 225, No. 6, Junie 1972, pp. 15-27.

15. Clark, R.W., The Role of the Bomber, Sidgwick and Jackson, London, 1977, p. 13 (vgl. ook pp. 9-35).

16. Brodie, B., Strategy in the Missile Age, Princeton University Press, Princeton, 1965, p. 152 (vgl. 00k pp. 107-144). Vgl. ook Clark, R.W., op. cit., pp. 117-123; Kohout, J.J., A Post B-1 Look at the Manned Strategic Bomber, in Air University Review, Vol. XXX, No. 5, Julie/Augustus 1979, p. 29.

17. Vgl. Cameron, N., Air Power and New Technology, in NATO's Fifteen Nations, Spesiale Uitgawe, No. 2, 1979, pp. 6-11; Ellis, R.H., Strategic Air Power, in RUSI, Vol. 125, No. 1, Maart 1980, pp. 3-7; Ellis, R.H., SAC's Duel Edged Sword, in NATO's Fifteen Nations, Vol. 25, No. 2, April/Mei 1980, p. 20: 'Since World War II, the manned bomber has been a visible symbol of military strength and the only system capable of responding throughout the entire range of conflict - quickly and effectively crossing the threshold between conventional and nuclear operations.'

18. Vgl. Speed, R.D., op. cit., pp. 83-84; Martin, A.B., The B-1. Strategic Deterrence into the Twenty-first Century, in Air University Review, Vol. XXVII, No. 3, Maart/April 1976, p. 4.

19. Vgl. Berman, R., The B-1 Bomber, in Johnson, D.T., Schneider, B.R. (reds.), op. cit., pp. 167-168; Kohout, J.J., op. cit., pp. 32-33; Quanbeck, A.H., Wood, A.L., Modernizing the Strategic Bomber Force. Why and How, The Brookings Institution, Washington, 1976, pp. 6-12.

20. Aangehaal in Kohout, J.J., op. cit., p. 32.

21. Vgl. Quanbeck, A.H., Wood, A.L., op. cit., pp. 39-84; Speed, R.D., op. cit. pp. 45-56.

22. Vgl. Martin, A.B., op. cit., pp. 4-5; Berman, R., op. cit., pp. 166-174 Kohout, J.J., op. cit., p. 50 - waar geantwoord word op die vraag hoekom 'n moderniseringsprogram vir die bomwerper noodsaaklik is: 'Because it would continue to stabilize our deterrent posture by providing the only system that can be manipulated before a nuclear strike is executed in order to signal resolve or perception of a threat of war or to eliminate prelaunch survivability.'

23. The Military Balance 1980-1981 ..., p. 3; Burke, G.K., A Case For the Manned Penetrating Bomber, in Air University Review, Vol. XXVIII, No. 5, Julie/Augustus 1977, pp. 22-26; Ellis, R.H., SAC's Duel Edged Sword .... pp. 20-23; Zumwalt, E.R., An Assessment of the Bomber-Cruise Missile Controversy, in International Security, Vol. 2, No. 1, Summer 1977, pp. 47-58.

24. Ellis, R.H., SAC's Duel Edged Sword ..., pp. 22-23.

25. Vgl. Martin, A.B., op. cit., pp. 5-8; Burke, G.K., op. cit., pp. 25-26; Kohout, J.J., op. cit., pp. 28, 40-51.

26. Vgl. Gray, C.S., The Strategic Forces Triad: End of the Road?, in Foreign Affairs, Vol. 56, №. 4, Julie 1978, pp. 771-789. 